See discussions, stats, and author profiles for this publication at: https://www.researchgate.net/publication/343217746

\title{
Extending Boundaries: Team Teaching to Embed Information Literacy in a University Module
}

Article in Mousaion · February 2020

Dol: 10.25159/2663-659X/6426

CITATIONS

3 authors, including:

Shehaamah Mohamed

University of the Western Cape

7 PUBLICATIONS 23 CITATIONS

SEE PROFILE

Some of the authors of this publication are also working on these related projects:

Literacies for Learning View project

Project use of mobile technologies View project

\section{READS}

18

Gerald Louw

University of the Western Cape

1 PUBLICATION 0 CITATIONS

SEE PROFILE 


\section{Extending Boundaries: Team Teaching to Embed Information Literacy in a University Module}

\author{
Sharita Bharuthram \\ https://orcid.org/0000-0003-0950-6430 \\ University of the Western Cape \\ sbharuthram@uwc.ac.za
}

\section{Gerald Louw}

https://orcid.org/0000-0002-0338-5255

University of the Western Cape

glouw@uwc.ac.za

\author{
Shehaamah Mohamed \\ https://orcid.org/0000-0002-1886-1429 \\ University of the Western Cape \\ shmohamed@uwc.ac.za
}

\section{Abstract}

In today's knowledge-based economy, the role of universities in preparing students to be information literate and independent thinkers and researchers is crucial. Information literacy (IL) skills enable students to become researchoriented, hold critical approaches to knowledge, be critical thinkers, consider things from different perspectives, develop their own ideas and defend and share these in an ethical manner. University students are often expected to access, process, evaluate and synthesise information from a number of sources in order to complete their assessment tasks. To do this efficiently, they need to possess good IL skills. This article postulates that students' IL skills can be successfully fostered and enhanced if academics and academic librarians enter into a partnership to collaboratively develop students' IL skills. The article discusses an intervention at the University of the Western Cape, South Africa that entailed embedding IL skills in an academic literacies (AL) course offered to first-year students in the Faculty of Community and Health Sciences. This intervention involved a partnership between academic librarians and an AL lecturer in adopting a team-teaching approach to collaboratively develop students' IL skills. Overall, students showed great enthusiasm for the IL sessions, and their responses to the different tasks given to them were positive. The partnership between the team members was found to be successful. Although the researchers concluded that a collaborative partnership between academics and academic librarians was feasible and sustainable, they acknowledged that the

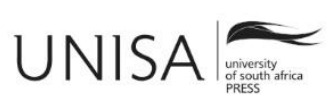

Mousaion: South African Journal of Information Studies https://upjournals.co.za/index.php/ Mousaion Volume 37 | Number 2 | 2019 |\#6426 | 18 pages

https://doi.org/10.25159/2663-659X/6426 ISSN 2663-659X (Online) | ISSN 0027-2639 (Print)

(C) Unisa Press 2020 
available resources within an institution, for example, library computer laboratories, might well impact on the decision to pursue such an initiative.

Keywords: information literacy; academic literacy; academic librarians; higher education; team teaching; collaborative partnership

\section{Introduction}

In the 21 st century, which is known as the information era, the crucial role of universities is to prepare their students to be information literate and independent thinkers and researchers (Moselen and Wang 2014). For over a decade, there has been increased pressure from various stakeholders, including the government and business sectors, for universities to produce graduates who possess the required information literacy (IL) skills to become life-long learners (Bendriss, Saliba, and Birch 2015). IL skills enable students to become research-oriented, hold critical approaches to knowledge, be critical thinkers, consider things from different perspectives, develop their own ideas and defend and share these in an ethical manner (Mohamed, in press). Hence it is essential that IL be viewed as an integral component of academic programmes. Although the outcome of many university programmes is stated as enabling students to access, process and evaluate information from multiple sources, academics expect students to come to university with the requisite skills. Additionally, the university orientation programme (which includes IL sessions) that students attend when entering university is generally perceived to be sufficient for them to acquire basic IL skills.

In the South African context, many students are, due to a myriad of reasons, not information literate; therefore they struggle to access the necessary and relevant information available in university libraries and/or use the information they do obtain to complete their research-based assignments successfully. For many of these students the exposure to IL during the orientation programme is insufficient to develop their confidence in using the resources available in the library. While some universities may offer additional library workshops during the course of the academic year, attendance by students is generally poor. The transition to university life, coupled with the challenges in meeting the IL expectations of academics, can have a negative effect on students' academic success. To assist students, academics can partner with academic librarians to collaboratively play an important role in enhancing students' IL skills. However, this role is often overlooked or not acknowledged, a situation that seems to be perpetuated by the pedagogical discourses of academics and academic librarians (Leckie and Fullerton 1999).

The role of academic librarians is succinctly encapsulated in the Framework for Information Literacy for Higher Education developed by the Association of College and Research Libraries (ACRL), a division of the American Library Association (2015). 
This framework "opens the way for librarians, faculty, and other institutional partners to redesign instruction sessions, assignments, courses, and even curricula; to connect IL with student success initiatives; to collaborate on pedagogical research and involve students themselves in that research; and to create wider conversations about student learning, the scholarship of teaching and learning, and the assessment of learning on local campuses and beyond" (American Library Association 2015, 3).

Drawing on the concept of multiliteracies and on the ACRL framework, this article reports on an intervention at the University of the Western Cape, South Africa that aimed to embed IL in the English for Educational Development (EED) module, which is an AL course offered to first-year students in the Faculty of Community and Health Sciences. To facilitate this intervention, two staff members from the library (a faculty librarian and an information literacy expert) (henceforth referred to as academic librarians) partnered with an AL lecturer in adopting an inclusive and collaborative team-teaching approach to assist students in acquiring literacy practices across different disciplines so as to be more successful in their studies, particularly in their first-year subjects. Fundamental to the EED module is the understanding that there are many different types of academic literacies (e.g. information literacy and computer literacy) that students must negotiate. According to Lea and Street (1998, 159), the academic literacies approach acknowledges "the requirement to switch practices between one setting and another, to deploy a repertoire of linguistic practices appropriate to each setting, and to handle the social meanings and identities that each evokes."

This article discusses how the intervention was designed and implemented, what the students' responses to the initiative were, and what successes and challenges were experienced by both the AL lecturer and the academic librarians. The aim of this article is to contribute to the ongoing scholarly debate on extending the boundaries of academics in different disciplines by using a collaborative team-teaching approach in partnership with academic librarians. It is hoped that the findings of this research will encourage and motivate academics to enter into collaborative partnerships with academic librarians in an endeavour to enhance students' IL skills and in so doing to enhance the quality of students' research-based assignments and ultimately to develop students with the requisite attributes to achieve success in today's knowledge-based economy.

\section{Literature Review and Theoretical Framework}

\section{Understanding Multiliteracies}

The understanding of what literacy entails has changed dramatically over the years. Traditionally, literacy was viewed as a non-complex phenomenon. However, in the mid1980s, the growing dissatisfaction of many students who felt alienated from the culture of teaching and learning in the classroom (despite the commitment of teachers) led to 
the emergence of a new approach to literacy development. According to this new approach, literacy is a socially contested concept grounded in an understanding that literacy is a socio-cultural practice and that there is, therefore, no single literacy but a multitude of literacies (Richardson 1998). For example, in order to succeed at university, students need "literacies" specific to the university (i.e. academic literacies) and specific to their particular disciplines (i.e. discipline-specific literacies). According to Thies (2012), students also need access to generic literacies such as traditional literacies and social and cultural literacies.

The concept of multiliteracies originated in 1994 when it was coined by the New London Group (1996) who sought to explore what constituted appropriate literacy teaching in the context of local diversity and global connectedness (Cope and Kalantzis 2000). Given the increasing cultural and language diversities among learners as well as the proliferation of information formats, twenty-first-century knowledge pro-sumers (i.e. producers and consumers) require a broad range of literacy skills or multiliteracies to function appropriately, not only in work and public spaces but also in their communities.

Based on their research, Cope and Kalantzis (2000) postulate that meaning is made in increasingly multimodal ways where texts interface with visual, audio, spatial and behavioural patterns of meaning. In a later study, Cope and Kalantzis (2006) propose that learners need to possess sufficient skills in language and grammar as well as skills to communicate effectively by using digital applications such as image manipulation, word processing and desktop publishing. A broad range of literacies is required to exercise these proficiencies, and teachers should be in a position to respond to the different mediums and modes, for example, in their recognition of IL as a set of multiple literacies, and to vary their modes of teaching to reflect these.

With regard to multiliteracies pedagogy, the New London Group (1996) advocates four components: situated practice, overt instruction, critical framing, and transformed practice. Situated practice involves engaging learners in meaningful and authentic lessons that take cognisance of their communities and backgrounds. Overt instruction involves the active scaffolding of learning interventions that assist learners in focusing on their learning experiences and tasks within the community of learners. The component of critical framing entails supporting and encouraging students to question common-sense assumptions found in discourses, and in doing this they are likely to become meaning-makers. Lastly, transformed practice involves students' use of their new understandings and the application of these in other contexts. Hence, teachers should develop ways for students to demonstrate their new understandings (New London Group 1996). The design of the intervention at the University of the Western Cape was guided by the four components mentioned above. 


\section{Using a Collaborative Approach}

In the last decade, researchers have increasingly advocated collaboration between academics and librarians, and many studies provide pedagogic justification for such collaboration (Bendriss, Saliba, and Birch 2015; Masella, Heidel, and Ke 2011; Moselen and Wang 2014; Pautz and Gauder 2017). In a collaborative approach, both parties work together "to identify what students need to know about accessing and retrieving information" (Otoide and Idahosa 2018, 65). It also entails co-teaching IL and assessing students' progress in retrieving information. A number of research studies have reported positive outcomes when using a collaborative approach. For example, Reed, Kinder, and Farnum (2007) found that after a semester-long intervention of integrating IL into a university preparation course, which had been developed through collaboration between the university librarians and faculty staff, students showed a clear improvement in IL skills. Their results showed that students who had scored 29 per cent in the pretest they had written upon entering the university, scored 85 per cent in the post-test written after the intervention. Similar findings were reported by Masella, Heidel, and $\operatorname{Ke}(2011,50)$ who found that students showed an "increased mastery of research skills" after they had been taught a series of IL skills which included, among others, locating relevant information, connecting to library resources remotely, using the library catalogue, and determining relevant sources. In addition, students' confidence levels in using these skills increased. Masella, Heidel, and $\operatorname{Ke}(2011,52)$ also found that collaboration helped to foster and model peer learning and teamwork among students. In the collaborative work undertaken by the researchers cited above, in particular, Reed, Kinder, and Farnum (2007), Masella, Heidel, and Ke (2011) and Otoide and Idahosa (2018), the design of their interventions varied according to the particular needs of the students and their respective programmes.

The method followed in the current study is discussed in the next sections. The discussion is guided by the literature that was reviewed and it draws on the pedagogy of multiliteracies.

\section{Background and Description of the IL Collaborative Team-Teaching Approach}

The initiative under discussion was undertaken in the English for Educational Development (EED) module - an AL course offered at the University of the Western Cape. AL courses in South Africa are part of the higher education/universities plan to enhance student throughput rates. The approach used in this EED module was aligned with the AL approach (Lea and Street 2006) according to which students are taught the various practices that their disciplines require. In order to make the module meaningful and relevant to students, discipline-specific assignments were used to teach the AL practices. Initially (i.e. prior to this initiative), the AL lecturer was solely responsible for teaching IL in the EED module. However, despite the inclusion of IL lessons in the 
module, many students still seemed to experience difficulty in understanding, finding, evaluating and using information. Furthermore, student evaluations often indicated that students experienced difficulty with research-driven tasks. In an attempt to address these problems, the AL lecturer initiated contact with the academic librarians, which led to the initiative of the collaborative team teaching of IL. The primary objective of the collaborative team-teaching approach was to provide students with a frame that they could use in EED as well as in their other subjects to support and better develop the acquisition of their IL competencies.

While the team-teaching approach used in this intervention involved the division of teaching responsibilities according to the strengths of each team member, in many instances there was an overlap of teaching responsibilities involving two members of the team who taught together. As such, although each member had specific section(s) to teach-commonly referred to as station teaching, where each member is responsible for a different part of the lesson-it was decided that in order to make this initiative a real team-teaching effort, any member of the team could participate by providing clarity and/or adding relevant information as and when necessary during a lesson presented by another team member. In addition, team members participated by assisting students in accordance with the one-teach/one-assist team-teaching approach. Existing studies provide evidence that students benefit more from library instruction if it is related to a specific assignment (Dhawan and Chen 2014). Therefore, to enhance the relevancy of the IL sessions, an AL assessment task (which was discipline-specific) was used as the basis for the IL tasks. The academic librarians had access to this assessment task prior to the intervention. Furthermore, to foster the effective development of students' IL skills, the various tasks were scaffolded (see Appendix 1).

The project was piloted in the first semester of 2018. The findings of the pilot project were used to revise the intervention, which was then re-introduced to a new cohort of students in the second semester of 2018. Two one-hour IL team-teaching sessions were added to the lectures in weeks 2 and 3. Both these IL sessions took place in the library computer room that had 30 computers. In an EED lecture prior to the IL sessions, students were given a research-based, discipline-specific assignment to complete during the course of the intervention, and the mark they obtained for it contributed towards their semester coursework mark.

In the first IL session, using the assignment as the basis for teaching, the IL expert introduced students to concept mapping. This lesson included an explanation of a concept map and its importance and how to develop one. Students then worked in groups to draw their own concept maps relating to the assignment topic. Thereafter, some groups presented their concept maps to the class. The next part of this IL session involved the use of uKwazi, which is the library search engine used to locate books. Using some of the keywords from students' concept maps, the academic librarian 
showed students how to access the uKwazi site and use different search possibilities. Students were able to follow and/or go through each step explained by the librarian on their computers. Thereafter, they practised accessing the uKwazi site by using their own keywords relating to their assignments.

The second IL session, which was held a week later, was a lesson presented by the EED lecturer on acknowledging sources, which included a discussion on why, when and how to reference. In preparation for this lesson, the academic librarians had made available to students a range of text sources, for example, books, journals, encyclopaedias, and dictionaries. At appropriate times during the lesson on referencing, the academic librarians intervened by demonstrating to students exactly where in the books particular information could be found, for example, the year of publication and the place of publication. Through this process, students were introduced to the general structure of a book in a subtle way. After the formal lecture, students were given the different text sources and asked to reference these in their groups. It must be noted that, as indicated earlier, although team members were responsible for different parts of the lessons, they had the flexibility to participate in each other's sessions by either clarifying or reenforcing information presented. Additionally, while a member was teaching a particular session, the other team members were actively involved in assisting students with the resources. Similarly, all team members assisted students during the group-work activities. This made for a truly collaborative team-teaching approach.

\section{Research Methodology}

Research context: This study was conducted at the University of the Western Cape, South Africa, by two staff members from the library (a subject librarian and an IL expert) and an academic staff member who coordinated and lectured a module called English for Educational Development (EED). The purpose of the EED module is to develop the literacy practices that students require to be successful in their respective disciplines. The main objective of this initiative was to enhance students' IL skills by strengthening the embedding of IL into the EED module through a collaborative teamteaching approach involving a faculty librarian and an IL expert. To achieve the aims of the current study, the researchers addressed the following key questions:

- What are students' perceptions of the different IL sessions?

- What are some of the successes and challenges of using a team-teaching approach?

- To what extent is the team-teaching approach feasible and sustainable?

A mixed methods research methodology was found to be suitable to achieve the above aims. According to Schoonenboom and Johnson (2017, 107), mixed methods research 
"combines elements of qualitative and quantitative research approaches for the broad purposes of breadth and depth of understanding and corroboration."

Participants: The participants comprised a total of 97 first-year university students registered in two departments in the Faculty of Community and Health Sciences. The two groups, one consisting of 37 students and the other of 60 students, were given separate sets of lectures. The students' ages ranged from 18 to about 25 years and there was a mixture of English first-language and English additional-language speakers.

Research instruments: Data was collected by means of an evaluation questionnaire that consisted of closed- and open-ended questions specifically designed to elicit responses about the two team-teaching IL sessions and to address the research questions. The informal discussions held after each IL session and the observations of the teamteaching members during the interventions were recorded individually and formed part of the data collection process. These records were expanded on later by each team member and collated by the EED coordinator.

Data analysis: The academic librarians did the initial analysis of all the data. The quantitative data obtained from the responses to the closed-ended questions in the questionnaire were counted and recorded. The qualitative data obtained from the responses to the open-ended questions were read, and keywords and phrases relating to the pre-determined codes drawn from the lessons' focus areas (i.e. concept mapping, uKwazi and referencing) were highlighted. In a second reading, the keywords and phrases were confirmed and the emergent codes, which Patton $(2014,555)$ describes as "recurring regularities," were categorised into sub-themes. These sub-themes were verified by the EED coordinator who did the final data analysis. Similar methods have been used by other researchers, for example, Patton (2014) and Robson and McCartan (2016). Additionally, the team members' observations were emailed to the EED coordinator, who produced an overall summary to obtain a holistic picture of the findings. These observations were also discussed in a follow-up meeting.

This research study adhered to the code of ethics of the University of the Western Cape. Ethical clearance was received to conduct the study and to publish the data. Steps were taken to ensure that the research was credible, dependable and confirmable (Shenton 2004).

\section{Findings and Discussion}

The responses to the open-ended questions centred mostly on the key concepts discussed during the lessons, namely, the lectures on concept mapping, uKwazi and referencing. Since these responses overlap with responses to the closed-ended questions, they are presented and discussed holistically in this article. 


\section{Students' Perceptions of the Different IL Sessions}

In order to obtain students' perceptions of the various IL lessons, they were asked to respond to the following questions: "Which part of the lessons did you enjoy the most? Explain your answer." "Which parts of the lesson did you enjoy the least? Explain your answer." The responses are provided below.

The lesson on referencing received the most positive responses from the students. For example, one student commented as follows: "I did not know how to reference and write in-text referencing. So this was exciting to learn as I will use it further. I enjoyed how it was presented" $\left(\mathrm{OT} 8^{1}\right)$. The two main reasons students gave for enjoying the lesson on referencing centred on the physical presence of the books and on learning about the variety and structure of books. The students appreciated the fact that they could handle the books and have hands-on practice in completing the different referencing tasks: "Physically having books to practise referencing" (P35); "Getting to reference books ourselves" (P50). The majority of the students (81\%) indicated that the books were very useful in helping them understand how to reference (see Table 1).

Table 1: Information sources and referencing

\begin{tabular}{|l|l|l|l|}
\hline Questions & Agree & Disagree & $\begin{array}{l}\text { No } \\
\text { response }\end{array}$ \\
\hline $\begin{array}{l}\text { I know why I have to acknowledge the ideas of } \\
\text { others. }\end{array}$ & 96 & & 1 \\
\hline $\begin{array}{l}\text { I know how to reference a book which has one } \\
\text { author. }\end{array}$ & 92 & 3 & 2 \\
\hline I know how to reference a journal article. & 86 & 8 & 3 \\
\hline $\begin{array}{l}\text { The presentation of the physical items in class } \\
\text { helped me to recognise and identify the } \\
\text { differences between books, journals and } \\
\text { encyclopaedias. }\end{array}$ & 84 & 9 & 4 \\
\hline $\begin{array}{l}\text { Were the books useful in helping you understand } \\
\text { how to reference? Yes/No. }\end{array}$ & 81 & 14 & 2 \\
\hline
\end{tabular}

With regard to the exposure to the different kinds of sources and learning about the general structure of books, some of the reasons provided for enjoying this included the following: "I was able to distinguish and recognise the different books and I was able to reference and identify the difference" (OT11); "Shown the back of the title page with all required information and how to use the index at the back to find relevant

\footnotetext{
${ }^{1}$ Student responses were coded numerically and according to their discipline group. For example, OT8 refers to Occupational Therapy student number 8. Similarly, P1 refers to Physiotherapy student number 1.
} 
information" (OT25); "Physically seeing the references in the book helped me to understand" (P38). Academics often take it for granted that students know the different kinds of text sources available in the library and the layout and/or structure of these. However, this may not necessarily be the case. Unfamiliarity with these aspects may be disadvantageous to a student who is new to the referencing of information.

Apart from the positive responses to the lesson on referencing, some students indicated that they had enjoyed this lesson the least. For example, one student wrote: "Referencing was so hard for me to understand" (OT5). Some research studies (see for example Hendricks and Quinn 2000) point out that referencing is a challenging task for novice students, and while students may acquire the technical conventions successfully, they may still have difficulty in understanding the texts and integrating their sources into their own writing, be it in the form of a quote, paraphrase or summary. The researchers observed this pattern in the current study. They noted that although students were able to follow the technical conventions taught in class, they were less successful and at times struggled with the tasks that required them to integrate a source into a quote, summary or paraphrase.

Other reasons provided by students for not enjoying the lessons on referencing were that they were too long and that the lecturer gave too many explanations: "A very, very long lecture, but it is to be expected" (P21); "Having to listen to the lecture content on the slides" (P1). It appeared that students were mostly concerned with the "how-toreference" component of the lesson rather than the "why-to-reference" and the "whento-reference" components which they regarded as the theory section. Apparently, these discussions bored the students. This may be due to the fact that academics generally tend to focus on getting the conventions correct without placing emphasis on why it is important to acknowledge one's sources. Given that the practice of referencing sources is an integral part of academic writing, it is important that students view referencing as a way of validating and/or enhancing their arguments.

Students also indicated that they had enjoyed the lessons on concept mapping. For example, students' responses included the following: "Doing the mind map helped me to start gathering information for my assignment" (P22); "[i]t gave me an idea how to go about starting my assignment" (P24). This finding is consistent with the data obtained from the closed-ended questions as presented in the Table 2. 
Table 2: Concept mapping

\begin{tabular}{|l|l|l|l|}
\hline Questions & Agree & Disagree & $\begin{array}{l}\text { No } \\
\text { response }\end{array}$ \\
\hline $\begin{array}{l}\text { Concept mapping will help me to organise and } \\
\text { structure my thoughts around the topic. }\end{array}$ & 93 & 4 & \\
\hline $\begin{array}{l}\text { I know how to brainstorm my topic and design a } \\
\text { concept map. }\end{array}$ & 93 & 4 & 1 \\
\hline $\begin{array}{l}\text { The lesson gave me insight into the various ways } \\
\text { to unpack and analyse my topic. }\end{array}$ & 87 & 9 & 2 \\
\hline $\begin{array}{l}\text { The facilitators were helpful when I encountered } \\
\text { difficulties with this lesson. }\end{array}$ & 95 & 2 & \\
\hline
\end{tabular}

From Table 2 it can be seen that a large percentage of students (93\%) saw the value of the concept map as a technique to help them organise and structure their thoughts around an assignment topic. In particular, 87 per cent of the students reported that the lesson had given them insight into the various ways to unpack and analyse their topic. In addition, a large majority of the students (93\%) indicated that they were now able to adequately brainstorm their assignment topic and design a concept map. It appeared that students not only found the lesson on concept mapping beneficial but they also particularly enjoyed the group work associated with this lesson. For example, students wrote: "Concept mapping was fun. We were in groups and were all involved, e.g. I was writing on a big page. So that was fun" (OT24); "The lessons where we formed groups in order to create a concept map, it showed me how useful it is especially in terms of breaking down an assignment" (P51); "The concept mapping, because I didn't have to listen to someone talking, rather I did something part-active" (OT26). However, a few students indicated that they had not enjoyed doing the practical exercises involving group work and presenting to the class as they did not "enjoy talking in front of everyone" (P1) as "it made [them] feel uncomfortable" (P18).

A few students indicated that they had found the lessons on uKwazi beneficial: "I enjoyed learning how to use uKwazi with the male demonstrator" (OT19); "Using the computers during lessons [was enjoyable]" (P34).

While the use of uKwazi was least mentioned by students in the open-ended questions, the responses to the closed-ended questions (as presented in Table 3 below) indicated that the lesson on uKwazi had been beneficial to students. 
Table 3: Locating information using uKwazi

\begin{tabular}{|l|l|l|l|}
\hline Questions & Agree & Disagree & $\begin{array}{l}\text { No } \\
\text { response }\end{array}$ \\
\hline $\begin{array}{l}\text { I know where to find the library catalogue called } \\
\text { uKwazi. }\end{array}$ & 96 & 1 & 2 \\
\hline $\begin{array}{l}\text { I know how to find books on my topic using } \\
\text { uKwazi. }\end{array}$ & 95 & 2 & 3 \\
\hline $\begin{array}{l}\text { I know how to save any material that I find using } \\
\text { uKwazi. }\end{array}$ & 49 & 45 & 1 \\
\hline $\begin{array}{l}\text { I will attend additional training sessions on uKwazi } \\
\text { in the library. }\end{array}$ & 38 & 58 & 1 \\
\hline
\end{tabular}

Table 3 shows that 96 per cent of the students indicated that they now knew how to access uKwazi whereas 95 per cent reported that they knew how to find books on their topic using the library catalogue. The fact that students used their own keywords from the concept maps they had drawn earlier on in the lesson might have made the sessions on uKwazi more beneficial and meaningful to them. However, of concern is that only 49 per cent of the students reported that they knew how to save materials that they found on uKwazi. On reflection, this finding could be due to the fact that the saving of information on uKwazi was demonstrated only towards the latter part of the lesson, leaving the students with insufficient time to practise saving information. Nonetheless, overall it appeared that the students felt confident in using the search catalogue - only 38 per cent of them indicated that they would attend additional training sessions. As with the findings relating to the lesson on referencing, students enjoyed the hands-on experience of being able to follow the instructor on their computers. For example, a student said it was enjoyable "[u]sing the computers to interact with what was being taught" (OT31). However, a few students expressed dissatisfaction with having to share a computer with other students as this prevented them from fully engaging in the task.

\section{Some of the Successes and Challenges of Using a Collaborative Team-Teaching Approach}

The collaborative team-teaching approach had benefits for the AL lecturer, the academic librarians and the students. Following a more embedded IL approach helped to enhance the quality of the EED lessons in that it made the lessons more meaningful to students and provided them with hands-on experience in accessing the uKwazi site and using the different text sources the librarians made available. Furthermore, having the lessons presented in the library provided students with a platform other than their usual lecture venue, which may have contributed to students' enthusiasm for the tasks they were given. The voices of different presenters and their different presentation styles also made the lessons lively. This was evident during the practical exercises; the team members observed that students actively engaged in the various tasks they were given. 
Using a collaborative team-teaching approach gave the academic librarians more insight into the EED module as it was easier to comprehend the structure and nature of the course content using this approach as opposed to working with students in an isolated ad hoc manner. Moreover, this approach enabled the academic librarians to integrate important concepts of the ACRL framework into the lessons via planned activities. In this way, the development of IL was no longer regarded as a unilateral library responsibility, which was restricted by the availability and schedule of a faculty librarian. Together, the academic librarians and the AL lecturer created an environment that portrayed the practical implementation of the notion of support from the parties involved. The collaborative approach also created a link for students to make contact with the academic librarians later on. The academic librarians made themselves available to assist students even after the IL sessions. The faculty librarian reported that the initiative encouraged EED students to schedule meetings with him and that they had consistently referred to the EED class as helpful. It may be inferred that the teamteaching approach promoted the development of a relationship between the students and the librarians and created a perception among students that they could trust the librarians. It seemed that students started to view librarians as an invaluable resource.

A critical component of this successful partnership was the mutual trust in and respect for each other's expertise that team members showed during the planning stages of the sessions and the delivery of the lessons. Although team members had the freedom to intervene during lessons where necessary to provide clarity in order to meet the outcomes of lessons, the AL lecturer observed that such interventions did not occur often. There was some hesitancy on the part of the academic librarians to intervene possibly because of their traditional non-teaching roles. The fact that this was their first participation in team teaching might also have been a contributory factor. It is anticipated that with further collaboration and more familiarity with each other's expectations and styles, this aspect could be strengthened and any existing barriers would be removed.

All team members agreed that the limited time available for the IL sessions was a challenge. It is acknowledged that in order for students to appreciate the many ways in which to engage with information, it is important that they be afforded ample time to discuss, design and present their interpretations regarding concept mapping, uKwazi and referencing activities. While this may be the ideal, it must be noted that EED is a semester module and it would therefore be difficult to dedicate more sessions to IL.

\section{Extent to Which the Team-Teaching Approach Is Feasible and Sustainable}

The adoption of a team-teaching approach required the holding of prior meetings in order to plan and structure the content and delivery of the lessons as well as the sharing of information so as to make sure that all team members had a common understanding. Although the process was time-consuming and might be off-putting, especially for 
lecturers, the advantage was that lessons were planned meticulously. As such, the integration of IL was done in a well-organised, embedded manner with all activities directly aligned with the learning outcomes of the lessons. It is expected that the initiation of any new intervention will initially require additional work. However, once a well-designed structure is in place, the expectation is that the workload will ease. The team members expressed the view that the approach presented above was feasible even for lecturers across various disciplines; however, they would need to re-visit their curriculum in order to embed the IL sessions. It has to be noted that the presentation of IL sessions does not have to be at the expense of the teaching of discipline content as the same content could serve as the basis for the activities in the library. Consequently, lecturers should be open to extending the boundaries as regards their view of the library and acknowledging that it is more than just a stand-alone resource.

Working around the logistics of such an intervention, such as the availability of information and communication technology facilities, may be challenging, especially at an institution with limited resources. This initiative was successful because the class size was relatively small. Implementing it for larger groups will require more appropriate information and communication technology facilities.

\section{Reflection}

Despite the challenge of having to work in a small computer laboratory, the EED collaborative team-teaching approach has been found to be successful in four consecutive iterations, and the initiative has elicited positive responses and feedback from students. This type of collaboration may be recommended for future EED classes because it fosters the development of crucial literacies in students through an active learning approach. While there is no doubt that the collaboration between the parties was successful, it could be expanded by including an assessment task directly related to the IL sessions, which would further strengthen the liaison between the AL lecturer and the academic librarians. Finally, the positive student feedback bears testimony to the success of the collaborative team-teaching approach described above. As such, it could serve as a model for a broader collaborative partnership between academics and academic librarians in embedding IL as an integral component of the curriculums of mainstream disciplines.

\section{References}

American Library Association. 2015. Framework for Information Literacy for Higher Education. Chicago: American Library Association, Association of College and Research Libraries. https://doi.org/10.5860/crln.61.3.207. 
Bendriss, Rachid, Reya Saliba, and Sally Birch. 2015. "Faculty and Librarians' Partnership: Designing a New Framework to Develop Information Fluent Future Doctors." Journal of Academic Librarianship 41 (6): 821-38. https://doi.org/10.1016/j.acalib.2015.09.003.

Cope, Bill, and Mary Kalantzis. 2000. Multiliteracies: Literacy Learning and the Design of Social Futures. London: Routledge. https://doi.org/10.1080/10572250701372847.

Cope, Bill, and Mary Kalantzis. 2006. "From Literacy to 'Multiliteracies': Learning to Mean in a New Communications Environment." English Studies in Africa 49 (1): 23-45. https://doi.org/10.1080/00138390608691342.

Dhawan, Amrita, and Ching-Jung Chen. 2014. "Library Instruction for First-Year Students." Reference Services Review 42 (3): 414-32. https://doi.org/10.1108/rsr-04-2014-0006.

Henricks, Monica, and Lynn Quinn. 2000. “Teaching Referencing as an Introduction to Epistemological Empowerment." Teaching in Higher Education 5 (4): 447-57. https://doi.org/10.1080/713699175.

Lea, Mary, and Brian Street. 1998. "Student Writing in Higher Education: An Academic Literacies Approach.” Studies in Higher Education 23 (2): 157-72. https://doi.org/10.1080/03075079812331380364.

Lea, Mary, and Brian Street. 2006. "The 'Academic Literacies' Model: Theory and Applications.” Theory into Practice 45 (4): 368-77.

Leckie, Gloria, and Anne Fullerton. 1999. "The Roles of Academic Librarians in Fostering Pedagogy for Information Literacy." Paper presented at the ACRL 9th National Conference, Detroit, MI, April 8-11, 1999. http://www.ala.org/acrl/sites/ala.org.acrl/files/content/conferences/pdf/leckie99.pdf.

Masella, David, Laura Heidel, and Irene Ke. 2011. "Integrating Reading, Information Literacy, and Literary Studies Instruction in a Three-Way Collaboration." Learning Assistance Review 16 (2): 41-53.

Mohamed, Shehaamah. (in press). "Decoding Information Literacy Ways of Thinking in Student Learning: Influencing Pedagogical Methods." South African Journal of Higher Education 34 (3).

Moselen, Chris, and Li Wang. 2014. "Integrating Information Literacy into Academic Curricula: A Professional Development Programme for Librarians at the University of Auckland." Journal of Academic Librarianship 40 (2): 116-23. https://doi.org/10.1016/j.acalib.2014.02.002. 
New London Group. 1996. “A Pedagogy of Multiliteracies: Designing Social Futures.”

Harvard Educational Review 66 (1): 60-92.

https://doi.org/10.17763/haer.66.1.17370n67v22j160u.

Otoide, Gloria P., and Mary E. Idahosa. 2018. "Faculty-Librarian Collaborations and Improved Information Literacy: A Model for Academic Achievement and Curriculum

Development." Journal of Library and Information Science 1 (1): 63-73.

Patton, Michael Q. 2014. Qualitative Research and Evaluation Methods. 4th ed. Thousand Oaks, CA: Sage.

Pautz, Michelle C., and Heide Gauder. 2017. "Undergraduate Research Needs: FacultyLibrarian Collaboration to Improve Information Literacy in Policy Papers." Journal of Public Affairs Education 23 (4): 1017-30.

https://doi.org/10.1080/15236803.2017.12002302.

Reed, Maureen J., Don Kinder, and Cecile Farnum. 2007. "Collaboration between Librarians and Teaching Faculty to Teach Information Literacy at One Ontario University: Experience and Outcomes." Journal of Information Literacy 1 (3): 29-46. https://doi.org/10.11645/1.3.28.

Richardson, Paul. 1998. "Literacy, Learning and Teaching.” Educational Review 50 (2): 115-35.

Robson, Colin, and Kieran McCartan. 2016. Real World Research. 4th ed. Chichester, West Sussex, United Kingdom: John Wiley and Sons.

Schoonenboom, Judith, and Burke Johnson. 2017. "How to Construct a Mixed Method Research Design.” Kölner Zeitschrift für Soziologie und Sozialpsychologie 69 (2): 107-31. https://doi.org/10.1007/s11577-017-0454-1.

Shenton, Andrew K. 2004. "Strategies for Ensuring Trustworthiness in Qualitative Research Projects.” Education for Information 22 (2): 62-75. https://doi.org/10.3233/efi-200422201.

Thies, Linda. 2012. "Increasing Student Participation and Success: Collaborating to Embed Academic Literacies into a Curriculum.” Journal of Academic Language and Learning 6 (1): 15-31.

\section{Appendix1: Information Literacy lessons}

\begin{tabular}{|l|l|l|}
\hline Session & Content & Presenter/Facilitator \\
\hline Session 1 & - Introduction to assignment & AL lecturer \\
\hline
\end{tabular}




\begin{tabular}{|c|c|c|}
\hline & $\begin{array}{l}\text { Concept mapping: } \\
\text { - Introduction to concept mapping } \\
\text { - Students work in groups to draw } \\
\text { concept map } \\
\text { - Groups present concept map } \\
\text { Using uKwazi: } \\
\text { - Students introduced to uKwazi } \\
\text { - Students practise finding keywords on } \\
\text { uKwazi }\end{array}$ & $\begin{array}{l}\text { IL expert } \\
\text { All team members } \\
\text { Faculty librarian }\end{array}$ \\
\hline Session 2 & $\begin{array}{l}\text { Researching information: } \\
\text { - Importance of researching information } \\
\text { / citing sources } \\
\text { - Students shown examples of different } \\
\text { sources } \\
\text { Locating information in a book / } \\
\text { Book structure: } \\
\text { - Students use books given to locate } \\
\text { information } \\
\text { Citing summarised and paraphrased } \\
\text { information: } \\
\text { - When, why and how to cite } \\
\text { information } \\
\text { - Working in groups, students choose } \\
\text { from their sources a sentence/phrase to } \\
\text { paraphrase or summarise and cite the } \\
\text { source } \\
\text { - Groups present their paraphrase/ } \\
\text { summary } \\
\text { Citing a quotation: } \\
\text { - When and how to quote information } \\
\text { - Working in groups, students choose } \\
\text { from their sources a sentence/phrase to } \\
\text { quote and cite the source } \\
\text { - Groups present their referenced } \\
\text { quotation } \\
\text { Providing a reference list: } \\
\text { - Working in groups, students write a } \\
\text { reference for the work they cited in the } \\
\text { task above. }\end{array}$ & $\begin{array}{l}\text { AL lecturer } \\
\text { Faculty librarian } \\
\text { IL expert }\end{array}$ \\
\hline
\end{tabular}

